Research Journal of Applied Sciences, Engineering and Technology 5(16): 4058-4065, 2013

DOI: 10.19026/rjaset.5.4625

ISSN: 2040-7459; e-ISSN: 2040-7467

(C) 2013 Maxwell Scientific Publication Corp.

Submitted: December 30, $2011 \quad$ Accepted: February 17, 2012

Published: April 30, 2013

\title{
Research Article \\ The Challenge of Liquid Transportation Fuels in Nigeria and the Emergence of the Nigerian Automotive Biofuel Programme
}

\author{
Elijah I. Ohimain \\ Bioenergy and Environmental Biotechnology Research Unit, Biological Sciences Department, Faculty of \\ Science, Niger Delta University, Wilberforce Island, Amassoma, Bayelsa State, Nigeria
}

\begin{abstract}
This study is aimed at assessing the challenge of liquid transportation fuel in Nigeria, which necessitated the entrance of the country into the biofuel race. The study found that despite being an important member of the organization of petroleum exporting countries (OPEC), Nigeria still suffers from fuel scarcities. Reasons for the short supply of refined petroleum products (particularly gasoline, diesel and aviation fuel) in Nigeria include poor capacity utilization of the nation's refineries, disruption of crude oil supply to the refineries and political instability in the Niger Delta region (Nigeria's oil province). Nigeria now relies heavily on foreign nations for the supply of these fuels. The country spends substantial part of her foreign exchange on fuel importation. The Federal Government now wishes to reverse this trend by initiating the automotive biofuel programme. The Nigerian automotive biofuel programme involved the construction of 9 plants comprising of 4 sugarcane and 2 cassava bioethanol projects and 3 biodiesel projects. These projects would involve the investment of $\$ 1.27$ billion into the Nigerian economy for the production of 445 million L of ethanol, $192 \mathrm{MW}$ of green electricity and 120 million L of biodiesel annually.
\end{abstract}

Keywords: Automotive biofuel, biodiesel, bioethanol, bioenergy, environmental impacts, petroleum

\section{INTRODUCTION}

Nigeria is a petroleum producing and exporting country. But like Libya, She is dependent on foreign nations for her liquid transportation fuels (mostly gasoline and diesel) produced via petroleum refining. Nations all over the world depends largely on refined petroleum products to meet their transportation energy requirements. Gasoline, diesel and aviation kerosene are the most common fuels used in the transportation sector. The increasing industrialization, globalization and motorization of the world has led to a steep increase for the demand for fossil fuels especially petroleum (Agarwal, 2007; Oniemola and Sanusi, 2009). When compression ignition engines were first developed, they were meant to run on ethanol and vegetable oils produced from biomass feedstock. However, gasoline and diesel emerged as the dominant transportation fuel in the early $20^{\text {th }}$ century and up till now because of the ease of operations with the materials available then for engine construction, and a growing supply of cheaper petroleum (Agarwal, 2007). Beyond these, petroleum based fuels are the preferred even among other fossil fuels. There are several reasons for the universal acceptance of petroleum based fuels. The fuel occurs in liquid forms, which made it easy and convenient to be transported through virtually all the fuel transportation modes including pipelines, trucks, tankers (land, water and air) etc. They are produced in liquid forms, refined and transported in liquid forms as well. Other fuels, like coal and biomass, occurs in solid forms and has several limitations in their transportation and distribution. Though, there are now proven technology for the pyrolysis, gasification and liquefaction of coal and biomass converting them to liquid fuels. Application of these technologies is still limited, for several reasons such as technological, commercial and environmental constraints. Currently, the existing infrastructure is most robust and widespread for petroleum than any other fuels. Such infrastructure include a networks of flow-lines linking oil wells to flow stations, several pipelines linking the flow stations to refineries, oil terminals, gas plants, and fuel depots from where fuels are delivered to filling/pump stations for distribution to consumers. Associated gas are separated from the crude oil, processed and compressed, transported through pipelines or tankers to the consumers. In the developed world, gas are delivered to households directly through the pipelines, while compressed natural gas (LNG) are used to run vehicles, trains, aircrafts and for the generation of electricity.

At today`s technology, no other primary energy source has as much ease, flexibility and cheap as petroleum. However, the continued use of fossil fuels 
has caused environmental, social and economic impacts, thus threatening sustainable development. There are remarkable impacts along the entire production and distribution chain of petroleum based fuels. The exploration, drilling and transportation, and refining of petroleum has caused a lot of impacts including deforestation to pave way for oil exploration, soil, water and sediment pollution during oil spills etc (Ogri, 2001). Oil spills are common in the Niger Delta principally due to the activities of vandals and illegal bunkers (World Bank, 1995; UNEP, 2011). During spills, biological entities in the spilled environment are impacted including the fisheries, upon which the indigenous people rely on for their survival. Farms, forests and other ecosystems are impacted, thus affecting the livelihood of the people. The people who are basically peasant farmers and gatherers of timber and non-timber products are impacted. The social and economic impacts of oil exploration especially on mangrove ecosystems can be over whelming. In addition, dredging, which is typically done to create navigable accesses for exploration, drilling, pipeline, and to support oil field logistics including the transportation of crude oil, result in environmental and social impacts (Ohimain, 2008a, 2008b). During dredging, dredged spoils are typically removed from the river and dumped overboard and abandoned, thus modifying the creeks by deepening, expanding the size and removing sharp bends and depositing the resultant dredged spoils as heaps at the bank of the dredged canals (Ohimain, 2011a). This has led to alteration in the topography and hydrology of the wetland ecosystem causing the death of mangroves vegetation and other associated flora and fauna including fisheries (Ohimain, 2004). Topographic changes in mangrove ecosystem also affect tidal inundation, spawning of fishes, while preventing mangrove propagules from establishing at these sites also permit the emergence of invasive species in the despoiled areas (Ohimain, 2010a). Also, acidification commences if the dredged spoils deposited are of mangrove origin. Dredged sediments from mangrove swamps contain pyrite $\left(\mathrm{FeS}_{2}\right)$, which are oxidized to sulphuric acid on exposure. The resultant acidification trigger a series of reactions in the ecosystem causing the river $\mathrm{pH}$ to drop below 4, killing vegetation, fishes and other aquatic biotic, block the canals and other drainage channel with ochre, smothering mangrove propagules and fish nesting sites and even causing the corrosion of oil field infrastructure. Acidification has led to the alteration of water chemistry resulting in heavy metal pollution (Ohimain et al., 2002, 2003, 2004, 2005, 2008a, 2008b, 2008c, 2009, 2010a, 2011a). Though, these impacts are localized within the areas of oil exploration, the socioeconomic effects are much wider. As a result of oil exploration related environmental impacts, wide spread agitation, illegal oil bunking, armed struggle, kidnapping and other social problems are now frequent in the Niger Delta.

There are other impacts of petroleum use that is globalized. The refining, transportation, distribution and use (combustion) of refined petrol has precipitated the most catastrophic human-induced environmental and social impacts. The increasing use of fossil fuels has also led to increasing air pollution, which is a major concern in most urban areas where automobiles are concentrated. It has been estimated that the global population of motor vehicles in use today is about 500 million, which is about 10 times more than what it was about 60 years ago and it was predicted that vehicle travel and fuel demand could triple resulting in greater air emissions (Agarwal, 2007). Air pollution resulting from the use of fossil fuels have been implicated in some health problems including eye irritation, heart problems, central nervous system disorders, drowsiness, coughing and other respiratory problems. The continued use of fossil fuel has been implicated in several global environmental problems such as green house effect, global climate change, acidification and ozone depletion. Most of those impacts are caused by rising $\mathrm{CO}_{2}$ levels and other products of fossil fuel combustion. Over the last 100 years, the atmospheric level of $\mathrm{CO}_{2}$ has almost doubled. The impacts of climate change are global and varied. It caused excessive rainfall in certain areas and drought in other areas. It has led to crop failures, thus aggravating the food security problems in many nations. Climate change has also caused increased incidences of natural disorders such as landslides, earth quakes, tsunamis, etc. The global climate change has also affected rainfall patterns. Global climate change is also implicated in extreme weather condition both in hot and cold climates, resulting in the changing disease patterns globally. The environmental, social and economic challenges of climate change have overwhelmed the world. In order to reverse this trend, the world met in Kyoto, Japan and made commitments for the reduction of green house gases (GHG). Annex 1 countries pledged and made definite commitments and targets for GHG reduction. Nigeria, like other non-Annex 1 countries made commitment for the reduction of GHG without any target. One of the major strategy for reducing GHG is the reduction in the use of fossil fuels through substitution with renewable fuels. Biomass derived fuel (biofuel) has emerged as the only liquid fuel that can substitute or replace fossil liquid fuels at today's technology and cost. Other technology such as solar energy, are also promising. They have been used mostly in small scale household electricity. Solar have also been considered for hybrid cars. The use of solar technology is restrictive. It is based on sunshine hours and intensity, which vary greatly all over the world. Biofuel on the other hand can be used as fuel to power vehicles, trains, aircrafts etc and as fuel to fire turbines 
and generator to generate electricity. Traditionally, biomass has been used in a combustion cycle either for heating/cooking or co-fired with coal to generate electricity. With current technology biomass can now be utilized as a feedstock for combined cycle electricity production via gasification. Through biomass, fossil energy carriers including gasoline, diesel and LPG have been successfully partially replaced by biofuels such as bio-ethanol, bio-diesel and biogas respectively. However, one of the major reasons given by many countries for entering the biofuel race is energy security. Every country wants to produce their energy domestically to prevent supply disruption and price volatility of crude oil. Nigeria, a major crude oil producing and exporting nation is also embarking on biofuel to overcome the constraints of domestic fuels availability in the country. The entrance of Nigeria into the biofuel sector is expected to spur rural development. Nigeria plan to integrate the petroleum sector with the agricultural sector, with the aim of boosting the agricultural and rural sectors. Rural transformation involves creating wealth, employment, good health services and other social infrastructures/ facility including road, water, sanitation, education, communication, and recreation etc for the sustenance of the rural people. Ogaboh et al. (2010) reported that the anticipated benefits of biofuel industry to rural communities in Nigeria include employment and wealth creation, rural infrastructure development, expansion of rural market, rural poverty reduction and skill acquisition and increase in school enrolment. The aim of this paper is to present the reasons why Nigeria embarked on biofuel, highlight the Nigerian automotive biofuel programme and bring to fore the challenges of biofuel production and use in Nigeria.

The challenge of automotive fuel use in Nigeria: Nigeria is blessed with abundant energy resources including 36 billion barrels of crude oil, 187 trillion scf gas, 2.7 billion tonnes of coal and lignite, 31 billion barrels of oil equivalent of tar sands, which has largely remained untapped. However, since 1956 when petroleum was discovered in commercial quantities in the Niger Delta, the country has installed extensive infrastructure for the production, transportation and refining of oil and gas. The country now has about 1500 oil wells in 160 oil fields producing 2.2-2.7 million barrels/day and flaring about 17 billion $\mathrm{m}^{3}$ of associated gas, releasing 2,700 tons of particulate, 160 tons of sulphur oxides, 5,400 tons of carbon monoxide, 12 million tonnes of $\mathrm{CO}_{2}$ and 3.5 million tons of methane (Oniemola and Sanusi, 2009). The country has 4 petroleum refineries, which are located in Port Harcourt (old and new) and each in Warri and Kaduna. The country also has 5 crude oil export terminals located in Escravos, Forcados, Brass, Bonny and Eket. There are also several floating production, storage and offloading

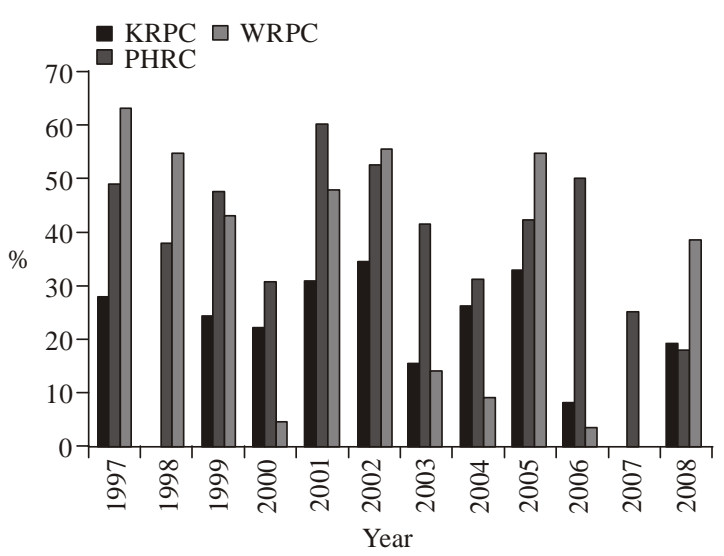

Fig. 1: Percentage capacity utilization of Nigeria's oil refineries from 1997-2008, NNPC (2008)

(FPSO). Nigeria has several pipeline networks linking the 4 refineries to several depots spread around the country, from where refined products are distribution to pump/filling stations using trucks. From these filling stations fuel are sold to the public. The country also has one functioning LNG located at Bonny Island. Two new LNG projects are in the offing. One of them, the Brass LNG is currently under construction, while the OK LNG is still undergoing feasibility. Nigeria has compressor stations located close to almost all the flowstations. The country also has gas processing facilities in Gbaran, Escravos, Forcados, Bonny, Kwale. The country has gas pipeline supplying gas to Benin, Togo and Ghana. While the country planned to extend the gas facilities to other West African countries, she also plans to extend gas pipeline through North Africa across the Saharan desert through the Mediterranean into Europe.

Despite the huge oil and gas investment and infrastructure, Nigeria is challenged by insufficient supply of refined petroleum products especially gasoline and diesel long queue of vehicles are common at filling stations especially during festive periods. Gasoline is sold at $\$ 65.00$ (\$0.42) per L, while diesel is sold at 112.00 (\$0.72) per L. The Government claims that they are subsidizing the price of refined products, without stating to what extent. Hence, the price of diesel and petrol are fixed but not subjected to market forces. The Government now intends to completely deregulate the downstream oil sector by the removal of subsidy.

The Government export over $85 \%$ of her crude oil, while the rest is left for domestic refining. Over the years, during to lack of maintenance, the 3 refineries are consistently working by far below their installed capacity (Fig. 1). There are cases of total shut downs even for months. Turn around and other routine maintenance are not done on schedules and are also very expensive perhaps due to poor tendering and negotiation process and corruption resulting in the inflation of maintenance costs. Of the 11.07 billion $\mathrm{L}$ of 
Res. J. Appl. Sci. Eng. Technol., 5(16): 4058-4065, 2013

Table 1: Sources of petroleum products consumed in Nigeria from 1997-2008, million metric tonnes (MMT)

\begin{tabular}{lllllllllllllll}
\hline & source & 1997 & 1998 & 1999 & 2000 & 2001 & 2002 & 2003 & 2004 & 2005 & 2006 & 2007 & 2008 \\
\hline $\begin{array}{l}\text { PMS } \\
\text { (gasoline) }\end{array}$ & $\begin{array}{l}\text { Domestic } \\
\text { refineries }\end{array}$ & 2,677 & 1,451 & 1,663 & 972 & 2,596 & 2,603 & 997 & 534 & 1,738 & 993 & 287 & 698 \\
& $\begin{array}{l}\text { Product } \\
\text { import }\end{array}$ & 1,062 & 2,507 & 1,987 & 4,144 & 3,857 & 4,036 & 5,404 & 5,696 & 5,483 & 5,408 & 5,792 & 4,596 \\
$\begin{array}{l}\text { HHK } \\
\text { (kerosene) }\end{array}$ & $\begin{array}{l}\text { Domestic } \\
\text { refineries } \\
\text { Product }\end{array}$ & 1,467 & 1,132 & 1,279 & 662 & 1,627 & 1,532 & 864 & 630 & 1,311 & 787 & 330 & 670 \\
& $\begin{array}{l}\text { N/A } \\
\text { import } \\
\text { Domestic } \\
\text { refineries }\end{array}$ & 2,353 & 1,611 & 1,814 & 1,048 & 2,522 & 2,516 & 1,432 & 1,179 & 2,123 & 1,260 & 623 & 1,166 \\
$\begin{array}{l}\text { AGO } \\
\text { (diesel) } \\
\text { Product }\end{array}$ & 185 & 516 & 465 & 1,953 & 117 & 405 & 1,147 & 211 & N/A & N/A & & N/A \\
\hline
\end{tabular}

petroleum product distributed in Nigeria in 2008, gasoline account for 69.3\%, diesel accounted for $11.07 \%$ while aviation turbine kerosene (ATK) accounted for $7.66 \%$ (NNPC, 2008). Automotive fuel therefore accounted for over $88 \%$ of the total refined product consumption in Nigeria. Between 2002-2007, on the average, petroleum products accounts for over $83 \%$ of the commercial primary energy consumed in Nigeria (Sambo, 2009). Details of the petroleum products consumed in Nigeria obtained from both domestic refining and imports are presented in Table 1.

Pipeline vandalism, oil spills and fire explosion/out breaks have increased in the past 10 years. This is due to the activities of armed militias that have emerged following the inequitable distribution of oil revenues in the country. The activities of the militias are restricted within the Niger Delta area, Nigeria's oil province. Their activities have not only affected the supply of crude oil to the refineries, they have also affected the distribution of refined products from the refineries and terminals to fuel depots. Because of these constraints, over $70 \%$ of transportation fuels used in Nigeria is imported. Nigeria now depends heavily on foreign nations for her domestic fuel needs. Imported fuels come into the country through the Niger Delta and Lagos due to the presence of oil handling infrastructure. Refined products sent through the Niger Delta also faced distribution challenges caused by pipeline vandalism.

The price volatility of crude oil at the international market is also affecting Nigeria adversely. Because the bulk of automotive fuel used in Nigeria is not domestically produced but imported, high prices of crude oil is affecting Nigeria as well, despite being an oil exporting country. The country is now spending a huge part of her foreign earning on the importation of automotive fuel. As the population of Nigeria continue to increase, there is an increasing demand for automotive fuel. Because of the current political instability in the Middle East, the prices of crude oil at the international market continue to rise. The Nigerian Government has continued to spend a substantial part of her earnings on fuel importation. Fuel importation is also hampered by logistic problems. With the Nigerian oil wells and infrastructure located in the Niger Delta, political disturbance, which is now frequent in the region, affects the distribution of automotive fuel in Nigeria almost bringing the country to a stand still. The government want to reverse this trend by diversifying her energy sources. Nigeria is now investing in biofuels in order to reduce her dependence on foreign nations for her refined products, thus increasing her energy security. The introduction of biofuel into Nigerian automotive fuel mix will increase the renewable share of Nigeria's energy. Besides, the country has good agro-climate for bioenergy feedstock spreading across the entire country unlike petroleum, which localized in the Niger Delta region. With biofuel, disturbance in one section of the country will not affect the automotive fuel distribution in the entire country. Agriculture used to be the mainstay of the country until the oil boom of the early 1970s, when Nigeria neglected the agricultural sector to focus on the oil sector. Although, Nigeria made much wealth from oil exportation, this has not translated to significant social benefits. Oil accounted for 29\% of Nigeria's GDP in 1980 and raised to 52\% in 2005. By contrast, Agriculture fell from a GDP of $48 \%$ in 1970 to $20.6 \%$ in 1980 and $23.3 \%$ in 2005 . Petroleum constitute the bulk of Nigeria's export, accounting for about 99\% of Nigeria's export and about $85 \%$ of Government earnings, whereas agricultural exports constitute about $0.2 \%$ of the country exports. Not withstanding, agriculture account for over $60 \%$ employment, while the petroleum sector only employs 4\% (Daramola et al., 2008). Nigeria now wishes to use the petroleum sector to boost the agriculture sector by investing in biofuels. The remaining part of the paper shall focus on the Nigerian biofuel programme, both prospects and challenges.

Nigerian automotive biofuel programme: In pursuance to an August 2005 Government directive on automotive biofuel, the Government released the Nigerian Biofuels Policy and Incentives (NNPC, 2007), which mandated the Nigerian National Petroleum Corporation (NNPC) to create a conducive environment for the take-off of a domestic biofuel industry. The aim is to gradually reduce the nation's dependence on imported gasoline, reduce environmental impacts while 
creating a commercially viable industry that can precipitate sustainable domestic jobs (NNPC, 2007). The policy approved the blending of biofuels as a component of fossil-based fuels in the country as required for all automotive use. The policy approved the blending of bio-ethanol up to $10 \%$ with gasoline to achieve E-10 blend, thus creating a current ethanol market demand of 1.3 billion L, which could increase to 2 billion L by 2020. The policy also approved a $20 \%$ blend of biodiesel with petro diesel creating an immediate biodiesel demand of 480 million L per annum, which could increase to 900 million L by 2020 . The policy aspires to achieve $100 \%$ domestic production of biofuels on or before 2020. But in the mean time, the policy specifies the seeding of the market through importation of bio-ethanol. The policy also mandated the NNPC to buy at an agreed price all the fuel ethanol produced in Nigeria. The policy made provisions for incentives to pioneering biofuel companies in Nigeria, which include tax holiday, income and withholding tax waivers, exception from custom duties, excise and VAT, long-term loans and insurance. About 20 large scale bio-ethanol projects have commenced following the release of the Nigerian Biofuel Policy and Incentives (Ohimain, 2010b, 2010c, 2010d, 2011b, 2011c, 2011d, 2011e, 2011f).

At the onset, the NNPC commenced 9 projects, which include 4 sugarcane ethanol, 2 cassava ethanol and 3 oil palm biodiesel projects (Table 2). The nine projects will require a land take of 146,374 ha, which the NNPC has already acquired. The cost of the projects is $\$ 1.27$ billion, which the Federal Government is funding through the NNPC in conjunction with other joint venture partners. The projects on completion will produce 445 million L of bio-ethanol per annum using 6-8 million tonnes of cassava and 7.2 million tonnes of sugarcane as feedstock. The four ethanol plants would generate 192MW of green electricity. The 3 biodiesel plants have a combined capacity of 120 million L/year. In addition, each of the sugarcane ethanol plant would create 2,500 direct jobs and 10,000 indirect jobs. Apart from the commencement of biofuel projects, the NNPC has made other progress towards advancing the use of biofuels in Nigeria, which include;

- Public awareness campaigns to encourage farmers to cultivate bio-energy crops particularly cassava and sugarcane

- $\quad$ Along with standard organization of Nigeria (SON) developed a quality assurance framework for biofuel importation and production

- Modification of depots (Atlas Cove and Mosimi) with the installation of biofuel handling infrastructure

- Training of depot staff on biofuel handling, QA/QC.
- Selection of retail outlet for the distribution of fossil fuels blended with biofuels (Ogaboh et al., 2010).

Potential challenges: One of the potential challenges of the automotive biofuel programme is land take. These nine projects were estimated to require 146,374 ha, which is about $28.5 \%$ of arable land not under cultivation in Nigeria. This is considered a high impact because Escober et al. (2009) reported that it would require 10 million ha of land if the entire world would implement E5. For the Nigerian automotive biofuel programme to require about $1 / 100^{\text {th }}$ of the global land requirement is considered a high impact. Besides, this land take would be used to produce 465 million $\mathrm{L}$ of ethanol and 120 million L of biodiesel per year which respectively accounted for 35.8 and $25 \%$ of bio-ethanol and biodiesel demand of the country. Hence, more land would be required to completely fulfil the 1.3 billion bio-ethanol and 480 million L of biodiesel demand under the automotive biofuel programme. In order to get the large expanse of land required for the cultivation of feedstock, farmers may be displaced from their farm land. Though, the NNPC has acquired the land for these projects and have compensated the land owners, but we doubt if the compensation can effectively mitigate the loss of farm land. The automotive biofuel project would require 6-8 million tonnes of cassava feedstock and 7.2 million tonnes of sugarcane per annum. These huge amounts of feedstock would require large input such as labour, water, fertilizer, pesticides, energy etc. The large labour input is an opportunity for employment, but we doubt if this employment can effectively mitigate the loss of traditional farm lands. Biofuel feedstock cropping will require large volume of water, which would be supplied through irrigation. Beyond these, ethanol fermentation and distillation processes require large volume of water.Large volumes of liquid wastes (effluents), solid wastes and gaseous emissions are release during the conversion of feedstock to biofuel. It has been estimated that about $12 \mathrm{~L}$ of stillage is generated for each litre of ethanol produced (Moreira and Serra, 1990).Except these wastes are converted to useful products such as animal feeds, fertilizer, biogas and power generation, they could pollute the environment. The Nigerian automotive biofuel project is designed to make use of waste bagasse for power generation and waste stillage for fertilizer and animal feed. As part of project design, effluents are to be used as farm irrigation water. Pesticides and fertilizer used in the farm could contaminate surface and ground water sources. Most of the projects are sited in rural communities. Most of the rural communities, lacked basic social amenities/infrastructure including roads, electricity, health centres, schools, banks, police post etc. while these infrastructural constraints could initially slow down the automotive biofuel projects, the 
Res. J. Appl. Sci. Eng. Technol., 5(16): 4058-4065, 2013

Table 2: Nigerian automotive biomass projects

\begin{tabular}{|c|c|c|c|c|c|c|c|c|c|}
\hline Project & Cost & Location & owners & $\begin{array}{l}\text { Feed } \\
\text { stock }\end{array}$ & $\begin{array}{l}\text { Feed stock } \\
\text { quantity, } \\
\text { tonnes/ year }\end{array}$ & $\begin{array}{l}\text { Project summary, } \\
\text { production / year }\end{array}$ & & $\begin{array}{l}\text { Land take, } \\
\text { ha }\end{array}$ & $\begin{array}{l}\text { Project } \\
\text { phase }\end{array}$ \\
\hline $\begin{array}{l}\text { Automotive } \\
\text { biofuel } \\
\text { project }\end{array}$ & $\begin{array}{l}\text { \$306 } \\
\text { million }\end{array}$ & $\begin{array}{l}\text { Agasha } \\
\text { Guma, } \\
\text { Benue State }\end{array}$ & $\begin{array}{l}\text { NNPC/ } \\
\text { private sector }\end{array}$ & $\begin{array}{l}\text { Sugar } \\
\text { cane }\end{array}$ & 1.8 million & $\begin{array}{l}75 \text { million } \\
\text { (ethanol), 116,81 } \\
\text { metric tons (sugar } \\
\text { 59MW (electricity }\end{array}$ & & $\begin{array}{l}20,000 \\
\text { (16,000 will } \\
\text { be } \\
\text { cultivated) }\end{array}$ & Planning \\
\hline $\begin{array}{l}\text { Automotive } \\
\text { biofuel } \\
\text { project }\end{array}$ & $\begin{array}{l}\$ 306 \\
\text { million }\end{array}$ & $\begin{array}{l}\text { Bukuru, } \\
\text { Benue state }\end{array}$ & $\begin{array}{l}\text { NNPC/ } \\
\text { private sector }\end{array}$ & $\begin{array}{l}\text { Sugar } \\
\text { cane }\end{array}$ & 1.8 million & $\begin{array}{l}75 \text { million } \\
\text { (ethanol), 116,81 } \\
\text { metric tons (sugar } \\
\text { 59MW (electricity }\end{array}$ & & $\begin{array}{l}20,000 \\
(16,000 \\
\text { will be } \\
\text { cultivated) }\end{array}$ & Planning \\
\hline $\begin{array}{l}\text { Automotive } \\
\text { biofuel } \\
\text { project }\end{array}$ & $\begin{array}{l}\$ 306 \\
\text { million }\end{array}$ & $\begin{array}{l}\text { Kupto, } \\
\text { Gombe state }\end{array}$ & $\begin{array}{l}\text { NNPC/ } \\
\text { private sector }\end{array}$ & $\begin{array}{l}\text { Sugar } \\
\text { cane }\end{array}$ & 1.8 million & $\begin{array}{l}75 \text { million } \\
\text { (ethanol), 116,81 } \\
\text { metric tons (sugar } \\
\text { 59MW (electricity }\end{array}$ & & $\begin{array}{l}20,000 \\
\text { (16,000 will } \\
\text { be } \\
\text { cultivated) }\end{array}$ & Planning \\
\hline $\begin{array}{l}\text { Automotive } \\
\text { biofuel } \\
\text { project } \\
\text { (Kwali } \\
\text { Sugarcane } \\
\text { ethanol } \\
\text { project) }\end{array}$ & $\begin{array}{l}\$ 80-100 \\
\text { million }\end{array}$ & Abuja, FCT & $\begin{array}{l}\text { NNPC/ } \\
\text { private sector }\end{array}$ & $\begin{array}{l}\text { Sugar } \\
\text { cane }\end{array}$ & 1.8 million & $\begin{array}{l}120 \text { million litre } \\
\text { (ethanol), } \\
\text { 15MW (electricity }\end{array}$ & & $\begin{array}{l}26,374 \\
\text { (estimated) }\end{array}$ & Planning \\
\hline $\begin{array}{l}\text { Automotive } \\
\text { biofuel } \\
\text { project }\end{array}$ & $\begin{array}{l}\$ 125 \\
\text { million }\end{array}$ & $\begin{array}{l}\text { Ebenebe, } \\
\text { Anambra } \\
\text { State }\end{array}$ & $\begin{array}{l}\text { NNPC/ } \\
\text { private sector }\end{array}$ & Cassava & 3 -4 million & $\begin{array}{l}40-60 \text { million } \\
\text { (ethanol) }\end{array}$ & & 15,000 & planning \\
\hline $\begin{array}{l}\text { Automotive } \\
\text { biofuel } \\
\text { project }\end{array}$ & $\begin{array}{l}\$ 125 \\
\text { million }\end{array}$ & $\begin{array}{l}\text { Okeluse, } \\
\text { Ondo State }\end{array}$ & $\begin{array}{l}\text { NNPC/ } \\
\text { private sector }\end{array}$ & Cassava & 3 -4 million & $\begin{array}{l}\text { 40-60 million } \\
\text { (ethanol) }\end{array}$ & $\mathrm{L}$ & 15,000 & Planning \\
\hline Biodiesel 1 & N/A & N/A & $\begin{array}{l}\text { NNPC/ } \\
\text { private sector }\end{array}$ & Oil plam & N/A & $\begin{array}{l}40 \text { million } \\
\text { (biodiesel) }\end{array}$ & $\mathrm{L}$ & 10,000 & Conception \\
\hline Biodiesel 2 & N/A & N/A & $\begin{array}{l}\text { NNPC/ } \\
\text { private sector }\end{array}$ & Oil plam & N/A & $\begin{array}{l}40 \text { million } \\
\text { (biodiesel) }\end{array}$ & $\mathrm{L}$ & 10,000 & Conception \\
\hline Biodiesel 3 & N/A & N/A & $\begin{array}{l}\text { NNPC/ } \\
\text { private sector }\end{array}$ & Oil plam & N/A & $\begin{array}{l}40 \text { million } \\
\text { (biodiesel) }\end{array}$ & $\mathrm{L}$ & 10,000 & Conception \\
\hline
\end{tabular}

Government has started installing these facilities to communities hosting biofuel projects. The automotive biofuel project has started attracting social benefits to rural communities.

After the initial success recorded during which feasibility studies and environmental impact assessment carried out and land acquired, the Nigerian automotive biofuel project execution is now slow. This may be due to lack of continuity by successive Government and lack of funds for the project. The automotive biofuel project is designed to be jointly funded by the Government and private sector. Hence, the NNPC is seeking for equity partners for the automotive biofuel programme. The Government through the NNPC is staking 20-49\%, while the state Government where the projects are located are willing to invest about 5\%, the rest is left for the private sector.

The fears of domination by large scale players has emerged early in the automotive biofuel sector. With a budget of over $\$ 1.26$ billion, only large scale multinationals can afford to invest in the automotive biofuel sector, to the detriment of small-scale processors. If due to financial constraints, the emerging automotive biofuel sector is dominated by the multinationals, then the social-economic benefits of the project will be limited. Then, it will end up like the upstream petroleum sector, which benefitted mostly the Government and the multinationals to the neglect of the smallholders. The mere opportunities of employment and business can not assure sustainable rural development. Unless the rural people are engaged in the entire biofuel product chain, the automotive biofuel project may not benefit the rural people. Malik et al. (2009) has reported a similar challenge faced by small holders in South East Asia. To over come this constraint, Ohimain (2011e, 2011f) suggested that project proponents should consider the construction of small-scale biofuel processing plants, which are within the operational capacity of the rural dwellers. Though, the automotive biofuel are designed to be integrated farm and bio-refinery, part of the feedstock would be sourced from the host communities. The sourcing of feedstocks from out growers could create opportunities for business and employment, it could also cause food versus fuel conflict. During land acquisition, the automotive biofuel project displaced some farmers from their farmlands, thus reducing available farmland in the community. Secondly, of the few available farmland left for the communities, some will be used to cultivate biofuel crops by the rural farmers. Thirdly, there is the tendency for competition between the traditional crops planted in the communities and biofuel feedstocks for land, water, fertilizer, pesticide, labour and other farm and non-farm inputs.

The Nigerian automotive biofuel programmes is designed to make use of cassava, sugarcane and oil 
palm feedstocks. These feedstocks are food crops consumed in many communities in Nigeria. Their diversion to produce biofuel could cause hunger especially in the rural areas, which is a threat to life and sustainability. The food stuff are converted to biofuel using conventional saccharification/hydrolysis, fermentation and transesterification. Hence, the resultant fuel produced is first generational (Ohimain, 2010b, 2010d, 2011b, 2011c). In order to avoid food versus fuel conflicts, other technologies are being considered for the production of biofuel using non-food feedstocks like short rotation crops/trees, wood and other agro-wastes, food wastes, grasses and municipal solid wastes (Ohimain, 2010c). Gasification technology is used to convert these biomass first to syngas comprising of $\mathrm{H}_{2}$ and $\mathrm{CO}$ which are converted to several other fuel and other energy carriers including hydrogen, methane, dimethyl ether, methanol, ethanol, heat, electricity, diesel, gasoline and many other chemicals (Ohimain 2011g). Zhang (2010) reported that the making of $\mathrm{H}_{2}$ and $\mathrm{CO}$ from biomass is widely recognized as important platform in the production of second generation bio-automotive fuels.

\section{CONCLUSION}

Nigeria is blessed with abundant energy and natural resources including oil and gas, nuclear elements, solar, wind and hydropower resources. But due to several constraints including disruption of crude oil supply to the nation's refineries by armed militants in the Niger Delta region coupled with the poor capacity utilization of the refineries, the supply of automotive fuel is unstable in Nigeria. Nigeria now rely on foreign nations for the supply of her refined petroleum products. The country now spends a substantial part of her foreign exchange for the importation of refined products to the detriment of the local economy. Nigeria has commenced the automotive biofuel programme, which involved the construction of 9 biofuel plants at the onset. The biofuel project will result in the injection of $\$ 1.27$ billion into the Nigerian economy. The projects involved the production of bioethanol from sugarcane and cassava feedstocks, biodiesel from oil palm and power generation from sugarcane bagasse. Other advantages of the project include employment creation, opportunity for business and energy security. But there are attendant environment impacts that must be addressed for the project to be sustainable including land take, food versus fuel conflict and environmental/ waste management.

\section{ACKNOWLEDGMENT}

The author wishes to thank Rohi Biotechnologies Ltd, and Sustainable Development Initiative, Port Harcourt, Nigeria for supporting this study.

\section{REFERENCES}

Agarwal, A.K., 2007. Biofuels (alcohols and biodiesel) applications as fuels for internal combustion engines. Prog. Energ. Combust., 33: 233,271.

Daramola, A., S. Ehui, E. Ukeje and J. McIntire, 2008. In: Collier, P., C.C. Soludo, and C. Pattillo, (Eds.), Economic Policy Options for a Prosperous Nigeria. Pelgrave Macmillan, Basingstoke, Hampshire, pp: 275-300.

Escober, J.C., E.S. Lora, O.J. Venturini, E.E. Yanez, E.F. Castillo and O. Almaran, 2009. Biofuels: Environment, technology and food security. Renew. Sustain. Energ. Rev., 13: 1275-1287.

Malik, U.S., M. Ahmed, M.A. Sombilla and S.L. Cueno, 2009. Biofuel production for smallholder producers in the Greater Mekong Sub-region. Appl. Energ., 86: 58-68.

Moreira, J.R. and G.E. Sierra, 1990. Alternative Fuels: Brazilian Outlook. In: Dessai, A.V., (Ed.), Alternative Liquid Fuels. New Age International Ltd Publishers, New Delhi, India, pp: 8-87.

NNPC, 2007. Draft Nigerian Bio-Fuel Policy and Incentives. Nigerian National Petroleum Corporation, Abuja.

NNPC, 2008. Annual Statistical Bulletin. Corporate Planning and Development Division (CPDD), Nigerian National Petroleum Corporation, Abuja.

Ogaboh, A.A.M., M.E. Ushie, M.I. Abam, M.S. Agba and J. Okoro, 2010. Developing the biofuel industry for effective rural transformation in Nigeria. Eur. J. Sci. Res., 40(3): 441-449.

Ogri, O., 2001. A review of the Nigerian petroleum industry and the associated environmental problems. Environmentalist, 21: 11-21.

Ohimain, E.I., T.O.T. Imoobe and M.O. Benka-Coker, 2002. Impacts of dredging on zooplankton communities of Warri River, Niger Delta. Afr. J. Environ. Poll. Health, 1: 37-45.

Ohimain, E.I. and T.O.T. Imoobe, 2003. Algal bloom in a newly dredged canal in Warri, Niger Delta. Niger. J. Sci. Res., 4: 14-21.

Ohimain, E.I., 2004. Environmental impacts of dredging in the Niger Delta; options for sediment relocation that will mitigate acidification and enhance natural mangrove restoration. Terra et Aqua, 97: 9-19.

Ohimain, E.I., W. Andriesse and M.E.F. van Mensvoort, 2004. Environmental impacts of abandoned dredged soils and sediments: Available options for their handling, restoration and rehabilitation. J. Soils Sediments, 4(1): 59-65.

Ohimain, E.I., M.O. Benka-Coker and T.O.T. Imoobe, 2005. The impacts of dredging on macrobenthic invertebrates in a tributary of the Warri River, Niger Delta. Afr. J. Aquat. Sci., 30: 49-53.

Ohimain, E.I., 2008a. Assessment of the impacts of dredging and drainage on the mangrove soils from selected rivers in The Niger Delta, Nigeria. Intl. J. Nat. Appl. Sci., 4(3): 299-304. 
Ohimain, E.I., J. Gbolagade and S.O. Abah, 2008a. Variations in heavy metal concentrations following the dredging of an oil well access canal in the Niger Delta. Adv. Biolog. Res., 2(5-6): 97-103.

Ohimain, E.I., 2008b. Application of moist incubation $\mathrm{pH}$ measurements for indicating wetlands acidification. Int. J. Biotech. Biochem., 4(3): 275282.

Ohimain, E.I., T.O.T. Imoobe and D.D.S. Bawo, 2008b. Changes in water physico-chemistry following the dredging of an oil well access canal in the Niger Delta. World J. Agric. Sci., 4(6): 752-758.

Ohimain, E.I., E.C. Agedah and F.O. Briyai, 2008c. Thioleaching of heavy metal contaminated sediments using Matin's medium. Int. J. Biotech. Biochem., 4(3): 263-273.

Ohimain, E.I., D.S. Olu and S.O. Abah, 2009. Bioleaching of heavy metals from abandoned mangrove dredged spoils in the Niger Delta: A laboratory study. World Appl. Sci. J., 7(9): 11051113.

Ohimain, E.I., 2010a. Aerobic bio-precipitation of heavy metal contaminated dredged materials from the Niger Delta. Res. J. Environ. Sci., 4(1): 93-100.

Ohimain, E.I., 2010b. Emerging bio-ethanol projects in Nigeria: Their opportunities and challenges. Energ. Policy, 38: 7161-7168.

Ohimain, E.I., 2010c. Available technologies for the conversion of waste biomass into energy. Paper presented at the $45^{\text {th }}$ Science Association of Nigeria (SAN) conference held at the Niger Delta University, Wilberforce Island, Bayelsa State, Nigeria (24-27 May 2010).

Ohimain, E.I., 2010d. First Generation Bio-Ethanol Projects in Nigeria; Prospects and challenges. FUTO Alternative Energy Conference, 16-20 May 2010, Owerri.

Ohimain, E.I., J.F. Bamidele and O.O. Omisore, 2010. The impacts of micro-topographic changes on mangroves of the Benin River, Niger Delta. Environ. Res. J., 4: 167-172.

Ohimain, E.I., 2011a. Indicators of wetland acidification and their relevance to environmental impact assessment. Int. J. Environ. Sustain. Dev., 10(2): 189-208.

Ohimain, E.I., 2011b. Evaluation of pioneering bioethanol projects in Nigeria following the announcement and implementation of the Nigerian biofuel policy and incentives. Energ. Sour. Part B: Econ. Plan. Policy, VOL: pp.
Ohimain, E.I., 2011c. First generation bio-ethanol projects in Nigeria: Benefits and barriers. Energ. Sour. Part B: Econ. Plan. Policy, VOL: pp.

Ohimain, E.I., 2011d. Diversification of Nigeria electricity generation sources. Energ. Sour. Part B: Econ. Plan. Policy, VOL: pp.

Ohimain, E.I., 2011e. Smallholder bioethanol production from cassava feedstock under rural Nigerian settings. Energ. Sour. Part B: Econ. Plan. Policy, VOL: pp.

Ohimain, E.I., 2011f. Environmental impacts of smallholder ethanol production from cassava feedstock for the replacement of kerosene household cooking fuel in Nigeria. Energy Sources Part A: Recovery, Utilization Environmental Effects, VOL: pp.

Ohimain, E.I., 2011g. The prospects and challenges of waste wood biomass conversion to bioelectricity in Nigeria. J. Waste Conver. Bioprod. Biotech., 1(1): 1-6.

Ohimain, E.I., E.N. Ogamba and L. Kigigha, 2011. Microbial leaching of heavy metal contaminated dredged materials using modified Starkey medium. Int. J. Biotechnol. Biochem., 7(4): 439-449.

Oniemola, P.K. and G. Sanusi, 2009. The Nigerian biofuel policy and incentives (2007); a need to follow the Brazilian pathway. International Association for Energy Economics, $4^{\text {th }}$ Quarter, pp: 135-139.

Sambo, A.S., 2009. Strategic Developments in Renewable Energy in Nigeria. International Association for Energy Economics. Third Quarter, pp: 15-19.

UNEP, 2011. Environmental Assessment of Ogoni Land. United Nations Environmental Programme.

World Bank, 1995. Defining an Environmental Development Strategy for the Niger Delta. Volume 1. West Central Africa Department, Washington DC.

Zhang, W., 2010. Automatic fuels from biomass via gasification. Fuel Processing Technol., 91(8): 866876. 